\title{
Evaluation of advanced bread spring wheat lines for field and seedling resistance to foliar pathogens
}

\author{
Elena I. Gultyaeva ${ }^{1, *}$, Ekaterina R. Shreyder ${ }^{2}$, Igor' $^{\prime}$ u. Kushnirenko ${ }^{2}$, Ekaterina L. \\ Shaydayuk $^{1}$, and Nadezhda M. Kovalenko ${ }^{1}$ \\ ${ }^{1}$ All Russian Institute of Plant Protection, Laboratory of Mycology and Phytopathology, 196608 \\ Saint Petersburg, Russia \\ ${ }^{2}$ Chelyabinsk Scientific Research Institute of Agriculture, Laboratory of Wheat Breeding, 456404 \\ Timiryazevski, Russia
}

\begin{abstract}
Foliar diseases (rusts and blotches) significantly limit the yield of spring wheat in the Southern Urals. The aim of the research was a comprehensive assessment of 17 promising lines of bread spring wheat, created at the Chelyabinsk Research Institute of Agriculture, for disease resistance and their identification of $L r$ genes. Resistance to leaf and stem rusts, Paraganospora nodorum leaf blotch and tan spot was studied in the field and laboratory conditions. All studied lines were characterized by high level of resistance to leaf and stem rusts in the seedling and adult plant stages. A wide representation of the $L r S p$ gene (individually or in combination with noneffective genes $\operatorname{Lr} 1, \operatorname{Lr} 3, \operatorname{Lr} 10, \operatorname{Lr} 9$ ), and genes $L r 24 / S r 24, L r 19 / S r 25$ and effective combinations of seedling $(L r 9+$ $L r 26 / S r 31)$ and adult plant (Lr34/Sr57 and $L r 21)$ resistance genes was revealed using molecular markers. Multiple resistance to rust and blotches (Paraganospora nodorum leaf blotch and tan spot) was detected in the Ferr. 26768 line. Molecular analysis showed the presence of adult plant resistance genes $L r 34 / S r 57+L r 21$ in combination with $L r 10$ gene. Along with diseases resistance, Ferr. 26768 line is promising in terms of a set of economically valuable attributes (lodging resistance, grain quality, yield).
\end{abstract}

\section{Introduction}

Spring wheat is a leading cereal crop in the Southern Urals. It occupies over $40 \%$ of cultivated areas of the region. Abiotic and biotic stresses significantly limit wheat productivity. The drought prevails as the abiotic stress, and as biotic stress - annual damage of wheat by leaf rust (pathogen Puccinia triticina). The harmfulness from leaf rust in some years can reach up to $37 \%$. Since 2010, an increase in the severity of stem rust ( $P$. graminis) and blotches (tan spot (Pyrenophora tritici-repentis) and Paraganospora nodorum leaf blotch has been observed in the region.

\footnotetext{
${ }^{*}$ Corresponding author: eigultyaeva@gmail.com
} 
Targeted selection for resistance to stress factors is ongoing at the Chelyabinsk Scientific Research Institute of Agriculture. In the State Register of Breeding Achievements of the Russian Federation [1], 68 spring wheat varieties are recommended for cultivation in the Ural region, of which 9 (Eritrospermum 59, Duet, Chelyaba 2, Chelyaba yubileynaya, Chelyaba stepnaya, Chelyaba 75, Uralskaya kukushka, Chelyaba ranyaya, Silach) were created at the Chelyabinsk Scientific Research Institute of Agriculture.

The expansion of the genetic diversity of new varieties is a priority for the breeding programs of the Chelyabinsk Scientific Research Institute of Agriculture. Donors of the $\operatorname{Lr} 9$ gene introduced from Aegilops umbellulata became widely popular in hybridization in the 1990s. This predetermined the high representation of the $\operatorname{Lr} 9$ gene in the Chelyabinsk varieties (Kvinta, Duet, Chelyaba 2, Pamyati Ryuba, Chelyaba yubileynaya, Chelyaba stepnaya, Chelyaba ranyaya). Mass cultivation of varieties with the $\operatorname{Lr} 9$ in the Urals and Western Siberia in 1995-2010 led to the pathogen's overcoming of their resistance. This necessitated the involving of new donors with genetic material from Agropyron elongatum, Ag. intermedium, Aegilops speltoides, Ae. tauschii, Ae. ventricosum, Secale sereale, and other wild wheat species. The Chelyaba 75 variety (v) was included in the State Register in 2012, which was created using "cuckoo" lines with the LrSp gene from Ae. speltoides [2], and in 2020 - the Silach variety with genes $L r 9$ and $L r 26$. Separately, the $L r 9$ and $L r 26$ genes lost their effectiveness in protecting against wheat leaf rust in the Southern Urals, while their combination is effective [3]. Use of molecular markers in order to identify resistance genes in wheat breeding material $[4,5]$ made it possible to significantly accelerate the pre-breeding process and select genotypes with target traits.

The aim of these studies was to characterize the advanced lines of bread spring wheat created at the Chelyabinsk Scientific Research Institute of Agriculture in their disease resistance in the seedling and adult plant stages, and to identify their resistance genes using molecular markers.

\section{Materials and methods}

The study included 17 lines of bread spring wheat, selected as promising for a complex of economically valuable traits (yield, grain quality, phenotypic assessment).

The resistance of wheat samples to foliar diseases was studied in the field at the infection nursery of the Chelyabinsk Scientific Research Institute of Agriculture in 2019. The disease severity of leaf and stem rust pathogens was assessed according to the Peterson scale [6], and blotches on the Saari and Prescott scale [7]. Seedling resistance was studied using 10-14-day old seedlings (first leaf stage), which were sprayed with an aqueous suspension of spores of the studied pathogens with Tween 80 detergent. After inoculation, the plants were placed in a Versatile Environmental Test Chamber MLR-352H (SANYO ElectricCo., Ltd., Japan) with controlled conditions (temperature $20{ }^{\circ} \mathrm{C}$, humidity $70 \%$, illumination 15000 lux, photoperiod 16 hours of daylight, 8 hours of night).

To study the resistance to wheat leaf rust, three test-isolates (k9, k19, k26) and the Chelyabinsk population of $P$. triticina (p_Ch) were used. Leaf rust inoculum was avirulent to the Thatcher lines with the genes $\operatorname{Lr24}, \operatorname{Lr} 28, \operatorname{Lr} 29, \operatorname{Lr} 39$ (=41), Lr45, Lr47, Lr50, Lr51, $L r 53$ and virulent to the Lr1, Lr2b, Lr2c, Lr3a, Lr3bg, Lr3ka, Lr14, Lr10, Lr18 and Lr30 genes. Virulence variation between test-isolates and population was observed on lines with the $\operatorname{Lr} 2 a, \operatorname{Lr} 9, \operatorname{Lr} 15, \operatorname{Lr} 16, \operatorname{Lr} 19, \operatorname{Lr} 20$ and $\operatorname{Lr} 26$ genes. Stem rust resistance was assessed using the Chelyabinsk population $P$. graminis, which was characterized by avirulence to lines with the $\operatorname{Sr} 24, \mathrm{Sr} 25$, and $S r 31$ genes. Resistance to rusts was evaluated 8-10 after inoculation using the Mains and Jackson scale for leaf rust and Stakman and Levine scale for stem rust [6]. Plants with a reaction type of $0,1,2$ were classified as resistant, $3,4, \mathrm{X}$ - as susceptible. 
Chelyabinsk populations of $P$. tritici-repentis and $P$. nodorum were used for evaluation of lines' resistance to tan spot and Paraganospora nodorum leaf blotch. The concentration of the suspension was $2-3 * 10^{3}$ conidiospores $/ \mathrm{ml}$. The resistance was evaluated in 6-7 days after inoculation using 5-scores rating scale [8]. Plants with a scores of 1, 2 were classified as resistant; with a score of 3 - as moderately susceptible, with a scores of 4, 5-as susceptible. Molecular markers were used for identifying 19 genes (Lr1, $\operatorname{Lr} 3 a, \operatorname{Lr} 9, \operatorname{Lr} 10, \operatorname{Lr} 19, \operatorname{Lr} 20$, Lr21, Lr24, Lr25, Lr26, Lr28, Lr29, Lr34, Lr35, Lr37, Lr41, Lr47, Lr51, LrSp) [4, 5, 9, 10, https://maswheat.ucdavis.edu].

\section{Results and discussion}

In 2019, a moderate development of foliar diseases (leaf and stem rusts and blotches) was observed at the infection nursery of the Chelyabinsk Scientific Research Institute of Agriculture. As in previous years, all breeding lines were resistant to leaf and stem rusts (Table 1). Ferr. 26768 line showed a high resistance to Septoria tritici blotch (no symptoms) and 11 other lines had a moderate susceptibility (disease severity up to $5 \%$ ). In the field, according to the visual symptoms, the absence $(0 \%)$ or moderate severity of tan spot (up to $5 \%$ ) were revealed in the studied lines.

As a result of a field assessment of the foliar diseases complex in the conditions of the Southern Urals in 2019, the Ferr. 26768 line with multiple resistance to rusts and blotches was designated.

In laboratory conditions, the studied lines showed a resistant reaction to all test-isolates and a population of $P$. triticina. When inoculated by test-isolate virulent to $\operatorname{Lr} 9$, a susceptible reaction was reveal only for Ferr. 26635 line. Based on the phytopathological test, the presence of $\operatorname{Lr} 9$ gene was predicted. Similar results were obtained for the Duet and Chelyaba 2 standard varieties that contain this gene. The reaction of the lines to the Chelyabinsk population of $P$. graminis varied from immune (score 0 ) to moderately resistant (score 2 ) and was higher than the commercial varieties Eritrospermum 59, Duet and Chelyaba 2. A high level of resistance of the studied lines to rust suggests that they are being protected by the highly effective $\mathrm{Lr}$ and $\mathrm{Sr}$ genes.

Most breeding lines showed a susceptible reaction when where inoculated by the Chelyabinsk population of P. nodorum in the seedling stage (score 5) (Table 1). Only two lines, Ferr. 26768 and Ferr. 26635, were characterized by a moderately susceptible type of reaction (score 3-4). At the same time, over $70 \%$ of the lines showed a resistant reaction (score $0-2$ ) to Chelyabinsk population of $P$. tritici-repentis, which is consistent with the results of the field studies.

As a result of a comprehensive assessment of resistance in the seedling and adult plant stages, a high level of resistance of the advanced lines to leaf and stem rusts was determined. Pedigree of lines differed, and this led to their genetic diversity in resistance. Ferr. 26768 line was characterized by multiple resistance to rusts and blotches (Paraganospora nodorum blotch and tan spot). 
Table 1. Resistance of bread spring wheat lines to foliar diseases in the seedling and adult plant stages

\begin{tabular}{|c|c|c|c|c|c|c|c|c|c|c|c|c|}
\hline \multirow[t]{3}{*}{ Line } & \multirow{2}{*}{\multicolumn{4}{|c|}{$\begin{array}{l}\text { Disease severity in the field } \\
(\%, \text { reaction type })\end{array}$}} & \multicolumn{7}{|c|}{$\begin{array}{l}\text { Type of reaction in the seedling stage } \\
\text { (score) }\end{array}$} & \multirow[t]{3}{*}{ Identified $L r$-genes } \\
\hline & & & & & \multicolumn{5}{|c|}{ Leaf rust } & \multirow[b]{2}{*}{ 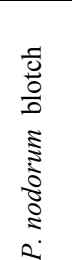 } & \multirow[b]{2}{*}{ 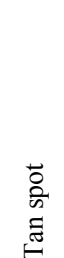 } & \\
\hline & 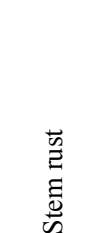 & 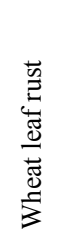 & 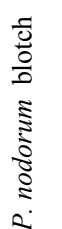 & 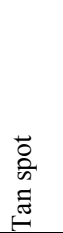 & $\begin{array}{l}\overrightarrow{0} \\
\vec{z} \\
\vec{\Xi} \\
\vec{D}\end{array}$ & k9 & \multicolumn{2}{|c|}{ k19 k26 } & p_Ch & & & \\
\hline Eritr. 26677 & 0 & 0 & 30 & 0 & $0-1$ & 0 & 0 & 0 & 0 & & & Lr1 Lr3 Lr10 LrSp \\
\hline Ferr.26688 & 0 & 0 & 30 & $0-1$ & 0 & 0 & 0 & 0 & 0 & 5 & 3 & $\operatorname{Lrl} \operatorname{LrSp}$ \\
\hline Eritr. 26701 & 0 & 0 & 10 & 5 & 2 & 0 & 0 & 0 & 0 & 5 & 1 & Lr3 Lr10 Lr9 Lr26 \\
\hline Lut. 26706 & 0 & 0 & 5 & 1 & $0-1$ & 0 & 0 & 0 & 0 & 5 & 1 & Lr3 Lr10 Lr19 \\
\hline Lut. 26714 & 0 & 0 & 5 & 1 & $0-1$ & 0 & 0 & 0 & 0 & $4-5$ & 2 & $\operatorname{Lr} 3 \operatorname{Lr} 9 \operatorname{Lr} 26$ \\
\hline Eritr. 26723 & 0 & 0 & 5 & 5 & $1-2$ & 0 & 0 & 0 & 0 & 5 & 2 & Lr24 Lr3 \\
\hline Eritr. 26740 & 0 & 0 & 5 & 1 & $0-1$ & 0 & 0 & 0 & 0 & 5 & 2 & Lrl Lr3 Lr10 Lr9 LrS \\
\hline Eritr. 26744 & 0 & 0 & 5 & 0 & 0 & 0 & $0-1$ & $0-1$ & 0 & 5 & 0 & $\operatorname{Lr} 10 \operatorname{Lr} 24$ \\
\hline Eritr. 26751 & 0 & 0 & 5 & 5 & $0-1$ & 0 & 0 & 0 & 0 & 5 & 0 & Lrl Lr3 Lr10 LrSp \\
\hline Ferr. 26768 & $\mathbf{0}$ & $\mathbf{0}$ & $\mathbf{0}$ & 1 & $\mathbf{0}$ & 0 & 0; & $\mathbf{0}$ & $\mathbf{0}$ & 3-4 & 2 & Lr10 Lr34 Lr21 \\
\hline Ferr. 26771 & 0 & 0 & 5 & 1 & $0-1$ & $0-1$ & 0 & 0 & 0 & 5 & 2 & Lr10 Lr34 Lr21 \\
\hline Lut. 26509 & 0 & 0 & 10 & 0 & 2 & 0 & 0 & 0 & 0 & 5 & 3 & Lr1 Lr10 LrSp \\
\hline Ferr. 26520 & 0 & 0 & 10 & 0 & $1-2$ & 0 & 0 & 0 & 0 & 5 & 2 & Lrl LrSp \\
\hline Ferr. 26536 & $1 \mathrm{MS}$ & 0 & 5 & $0-1$ & $1-2$ & 0 & 0 & 0 & 0 & 5 & 3 & Lr10 Lr34 Lr21 \\
\hline Ferr. 26577 & $1 \mathrm{~S}$ & 0 & 5 & 0 & $0-1$ & $0-1$ & 0 & 0 & 0 & 5 & 1 & Lr10 Lr34 Lr21 \\
\hline Barbarossa 26607 & $1 \mathrm{MR}$ & 0 & 5 & 0 & $1-2$ & 0 & 0 & 0 & 0 & 5 & 3 & $L r S p$ \\
\hline Ferr. 26635 & $1 \mathrm{MS}$ & 1 & 5 & 0 & 2 & 3 & - & 0 & 0 & 4 & 3 & $\operatorname{Lr} 9$ \\
\hline Standards & & & & & & & & & & & & \\
\hline Eritr.59 & $10 \mathrm{~S}$ & $20 \mathrm{~S}$ & 10 & 0 & 3 & 3 & 3 & 3 & 3 & 5 & 3 & \\
\hline Duet & $20-30 \mathrm{~S}$ & $1 \mathrm{~S}$ & 10 & 1 & 3 & 3 & 0 & 0 & 0 & 5 & 3 & $\operatorname{Lr} 9 \operatorname{Lr} 10$ \\
\hline Chelyaba 2 & $10-20 \mathrm{~S}$ & $1 \mathrm{~S}$ & 5 & 0 & 3 & 3 & 0 & 0 & 0 & 5 & 3 & $\operatorname{Lr} 9 \operatorname{Lr} 10$ \\
\hline Chelyaba 75 & $1 \mathrm{MR}$ & 0 & 10 & 1 & 2 & 0 & 0 & 0 & 0 & 5 & 2 & Lr1 Lr10 LrSp \\
\hline
\end{tabular}

Reaction: $M R$ - middle resistance (score 1-2), $M S$ - middle susceptible (scores $3^{-}, X$ ), $S$ susceptible (score 4).

Identification of resistance genes by molecular markers showed a wide representation of the $L r S p$ gene, which is highly effective in leaf rust resistance in the studied lines (41\%), both individually and in combination with noneffective genes ( $\operatorname{Lr} 1, \operatorname{Lr} 3, \operatorname{Lr} 10, \operatorname{Lr} 9)$ (Table 1). Translocation with highly effective genes $L r 24 / S r 24$ was detected in the Eritr. 26723 and Eritr. 26744 lines, and with the Lr19/Sr25 genes - in the Lut. 26706 line. An effective combination of the $\operatorname{Lr} 9$ and $L r 26$ genes has been identified in the Eritr. 26701 and Lut. 26714 lines. In the translocation with the $L r 26$ gene, there is also a stem rust resistant gene $\mathrm{Sr} 31$, which is highly effective in Russia. Adult plant resistant genes $\mathrm{Lr} 34 / \mathrm{Sr} 57$ and $\mathrm{Lr} 21$, in combination with the noneffective $\operatorname{Lr} 10$ gene were revealed in four lines - Ferr. 26768, Ferr. 26771, Ferr. 26577, Ferr. 26536. Only one $\operatorname{Lr} 9$ gene was detected at the Ferr. 26635 line, that is consistent with the results of the phytopathological test. However, a high level of rust resistance of this line suggests the presence of additional genes.

Molecular screening made it possible to explain the high level of resistance of the studied material to rust. The $\operatorname{Lr} 24 / \operatorname{Sr} 24, \operatorname{Lr} 21$ genes are highly effective not only in the Southern Urals, but also in other regions of the Russian Federation.

Taking into account all field and laboratory assessments, the Ferr. 26768 line proved to be the most promising with multiple resistance to rusts and blotches. Its yield in 2019 was 6 hundred $\mathrm{kg}$ per hectare higher than the standard variety with $\mathrm{HCP}_{05}$ of 3.2 hundred $\mathrm{kg}$ per hectare. This sample is highly resistant to lodging, weakly affected by common bunt, in grain 
quality meets the requirements for valuable and solid wheat: protein content of $14.3 \%$, gluten $29.3 \%, 1000$ grain weight $-45.7 \mathrm{~g}$.

\section{Conclusion}

A new breeding material of bread spring wheat has been created, combining disease resistance with adaptability to adverse environmental factors, high yield and grain quality. Molecular analysis showed a high genetic diversity of all lines in terms of resistance to leaf and stem rusts. A promising Ferr. 26768 line with multiple resistance to fungal foliar pathogens and economically valuable traits was designated, significantly exceeding standard varieties.

The current research was supported by RFBR grant No. 19-016-00052a.

\section{References}

1. State Register for Selection Achievements Admitted for Usage (National List) 1, (Moscow: FGBNU "Rosinformagrotekh", 2020)

2. V. A. Tyunin, E. R. Shreider, E. I. Gultyaeva, E. L. Shaydayuk, Vavilov J. Genet. Breed 21, 523 (2017). DOI: 10.18699/VJ17.269

3. E. I. Gultyaeva, BIO Web of Conf. 18, 0013 (2020). DOI: $10.1051 /$ bioconf $/ 20201800013$

4. L. Błaszczyk, I. Kramer, F. Ordon, J. Chełkowski, M. Tyrka, J. Vida, I. Karsai, Cereal Res. Comm. 36, 201 (2008). DOI: 10.1556/crc.36.2008.2.1

5. B. D. McCallum, C. W. Hiebert, S. Cloutier, G. Bakkeren, S. B. Rosa, D. G. Humphreys, G. F. Marais, C. A. McCartney, V. Panwar, C. Rampitsch, B. J. Saville, X. Wang, Can. J. Plant Pathol. 38, 1 (2016). DOI: 10.1080/07060661.2016.1145598

6. R. A. McIntosh, C. R. Wellings, R. F. Park, Wheat rusts. An atlas of resistance genes (CSIRO Australia, Kluwer Acad. Publ., Dordrecht, the Netherlands, 1995)

7. E. E. Saari, J. M. Prescott, Plant Dis. Rep. 59, 377 (1975)

8. L. Lamari, C. C. Bernier, Can. J. Plant Sci. 11, 49 (1989). DOI: 10.1080/07060668909501146

9. G. F. Marais, T. A. Bekker, A. Eksteen, B. McCallum, T. Fetch, A. S. Marais, Euphytica. 171, $71(2010)$

10. L. S. Vanzetti, P. Campos, M. Demichelis, L. A. Lombardo, P. R. Aurelia, L. M. Vaschetto, C. T. Bainotti, M. Helguera, Electronic Journal of Biotechnology 14 (2011). DOI: $10.2225 /$ vol14-issue3-fulltext-14 